\title{
HUMAN IMPACT ON THE RIVER CHANNELS MORPHOLOGY IN THE HIMALAYAS AND ITS PIEDMONT (INDIA)
}

DOI: http://dx.doi.org/10.18509/GBP.2019.24

UDC: 556.537:556.18(540)

\author{
Lukasz Wiejaczka \\ Institute of Geography and Spatial Organization, \\ Polish Academy of Sciences, Poland
}

\begin{abstract}
The aim of the study is the presentation of the directions and scale of changes in the morphology of the Himalayan and its piedmont river channels occurring under the contemporary influence of human activity. The study uses the results of morphological field research conducted in the Teesta river basin (right tributary of the Brahmaputra) in the period 2011-2015. The research shows that one of the most common anthropogenic form affecting banks of the Himalayan channels is their reinforcement and reprofiling related to bridges and dams construction. In turn, on the Himalayan piedmont, the most visible human influence is massive extraction of riverbed sediments what leads to the deepening of river channels. The morphological changes of channels caused by human interference deteriorates the quality of the rivers habitat and affects human communities dependent on rivers ecosystem services.
\end{abstract}

Keywords: rivers, channel morphology, human impact, Himalayas, India

\section{INTRODUCTION}

Environmental conditions of rivers are changing over multiple spatial and temporal scales under influence of natural factors and diverse human activities [1]. The role of various forms of anthropopressure in channel systems is particularly discussed in the environmental literature, e.g. [2], [3]. Human activities in river ecosystems can be direct (including channels regulation, construction of dam reservoirs) and indirect (containing land use and land cover changes), and their consequence is a change in type, as well as spatial diversity of the intensity of morphogenetic processes [4], [5]. Human effects on mountain streams lead among others to the changes in channel geometry, dynamics of water and sediment movement, contaminants in the stream, or aquatic and riparian communities [6]. [7] states that human activity leads to the transformation of the natural environment into more homogeneous and with a low diversity. Human impact on river ecosystems is particularly noticeable in highly populated areas where rivers are a main source of ecosystem services [8].

Rivers in the Himalayas and its piedmont have highly dynamic environment with extreme variability in discharge and sediment load and are characterized by frequent changes in shape, size, position and planform [9], [10]. Simultaneously, the Himalayas and its piedmont are places of strong human interference in the natural environment [11], [12].

The aim of the study is the presentation of the directions and scale of changes in the morphology of river channels in the Himalayas and its piedmont occurring under the contemporary influence of human activity. The study uses the results of gemorphological field research conducted in the Teesta river basin (right tributary of the Brahmaputra) in the period 2011-2015 (Fig. 1). The investigations were carried out during 5 scientific 
expeditions realized under cooperation between Polish Academy of Sciences and Indian National Scientific Academy as well as under collaboration of the Institute of Geography and Spatial Organization and North Bengal University.

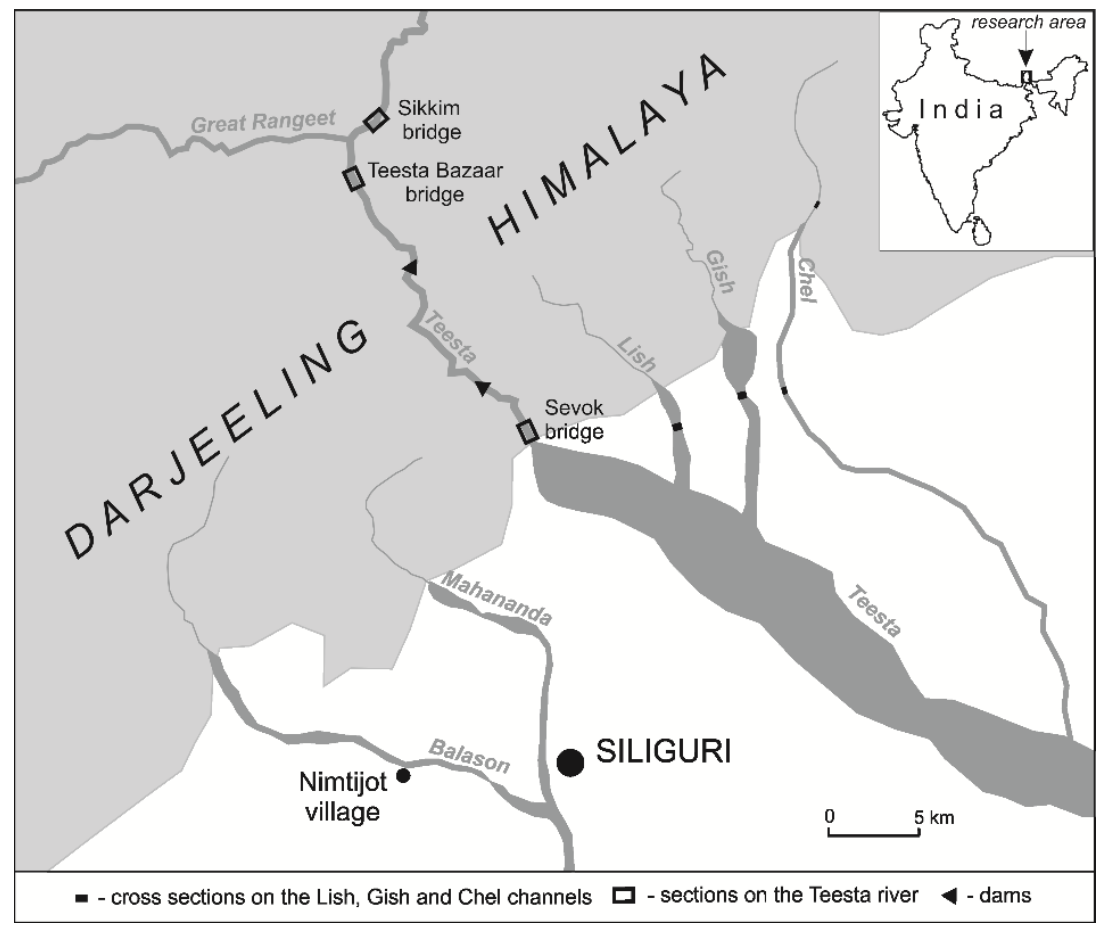

Figure 1. Study area

\section{STUDY AREA AND METHODS}

The field researches were mainly conducted on the Teesta river and its tributaries within the Darjeeling Himalayas and its piedmont (Fig. 1). The Teesta river is a right tributary of the Brahmaputra with draining mountain area of approximately $8,600 \mathrm{~km}^{2}$. It originates in the Pauhunri massif (7127 $\mathrm{m}$ a.s.l) and the total length of mountain section of the river amounts to $182 \mathrm{~km}$. The Teesta is characterized by a complex hydrological regime with rain, glaciers and snow melting as well as groundwater supply. According to [13] the total annual rainfall fluctuates usually in this area between 2000 and $6000 \mathrm{~mm}$. Approximately $80 \%$ of the annual precipitation falling during the monsoon season [14]. Maximal river flow registered on 4th October 1968 (in Teesta Bazaar) was estimated at $18150 \mathrm{~m}^{3} \cdot \mathrm{s}^{-1}$ and the minimal flows during dry season drop below $20 \mathrm{~m}^{3} \cdot \mathrm{s}^{-1}$ [15]. In the analyzed mountain section, the width of the channel within the valley of the Teesta ranges from $20 \mathrm{~m}$ to 200 $\mathrm{m}$. The slopes of the valley of the Teesta are shaped by landslide processes, which are especially active during intensive precipitation and high water flows [16].

Lish, Gish and Chel rivers are a first large left-bank tributaries of the Teesta river in the piedmont zone of the Himalayas. The total length of the rivers is respectively $20 \mathrm{~km}, 41$ $\mathrm{km}$ and $63 \mathrm{~km}$. In the mountainous part of the rivers their valleys are deeply cut in the metamorphic rocks of various geological units. On the foreland of the mountains, the river beds are filled with alluvial material that forms extensive fans (Lish and Gish) with lengths up to dozen and a width of up to few kilometers [17]. From the study of [15] results that on the studied rivers Lish, Gish and Chel, every several years occur very large or even catastrophic floods causing transformations of the river channel morphology. 
The geomorphological works on the Teesta were carried out (in 2012) during investigation of the hydromorphological state (with using the River Habitat Survey methodology) of the mountain section of the river (33-kilometer length) between Sikkim border and outlet from Himalaya (Sevok bridge). Field studies on the Lish, Gish and Chel rivers were based on the 4-fold measurements of morphometry of the riverbeds in four designated cross-sections. The research was carried out in the years 2011-2014. Three cross-sections have been located in the mountain piedmont along the bridges on the national highway connecting West Bengal and Assam at a distance of $3 \mathrm{~km}$ from the Himalayas (Lish), $4 \mathrm{~km}$ (Gish) and $11 \mathrm{~km}$ (Chel). Additionally, in order to illustrate the tendencies of morphological changes in river beds in the mountainous area, one cross profile of the Chel riverbed was determined along a road bridge located in the Himalayan part of the drainage basin, about $2 \mathrm{~km}$ above the mountain border.

In addition social studies were conducted among population living off the extraction of bed material from the Balason river (the tributary of the Mahananda river in the Ganga basin) in the Himalayan piedmont. The studies aimed to illustrate the relationship between local communities and the morphology of riverbeds. The community of the Nimtijot village was selected for investigation. Information on the local community's social and economic standing and its relation with the river ecosystem were collected through a diagnostic survey in the form of interview conducted in 2015.

The detailed description of the methodology use in the above mentioned investigations contain publications [17], [18], [19].

\section{RESULTS AND DISCUSSION}

\section{Human interference in the morphology of Himalayan rivers}

The main natural factor affecting the morphology of Himalayan rivers is frequency and magnitude of floods caused by high rainfalls [13], [15]. The consequence of floods (in combination with rising of mountains) is deepening of channels as a common natural morphological process in the Himalayan rivers [11], [20]. The measurements of crosssection located in the mountain part of the Chel river conducted in the period 2011-2014 confirm a trend towards deepening of the Himalayan channels. The depth of the Chel channel in 2011 ranged from 5.25 to $6.45 \mathrm{~m}$. In 2014, the depth was in the range of 5.45$6.30 \mathrm{~m}$. The course of the average depth of the Chel channel shows a trend towards deepening, up to $1 \mathrm{~cm} /$ year (Tab. 1). Local deepening of the channel during a year reached $0.50 \mathrm{~m} \mathrm{[17].}$

Table 1. Average depth of the Lish, Gish and Chel river beds in 2011-2014

\begin{tabular}{|l|r|r|r|r|}
\hline \multicolumn{1}{|c|}{ River } & \multicolumn{1}{c|}{2011} & \multicolumn{1}{c|}{2012} & \multicolumn{1}{c|}{2013} & \multicolumn{1}{c|}{2014} \\
\hline Lish & 3.62 & 3.57 & 3.55 & 3.51 \\
\hline Gish & 5.85 & 5.83 & 5.84 & 5.83 \\
\hline Chel (piedmont) & 6.21 & 6.05 & 6.23 & 6.32 \\
\hline Chel (mountains) & 5.74 & 5.72 & 5.74 & 5.77 \\
\hline
\end{tabular}

The modifications concerning the morphology of channel banks are one of the a major form of anthropogenic pressure in the channel within the Himalayan part of the Teesta river [18]. Reinforcements with a concrete walls and reprofiling of riverbanks is observed for example at the location of bridges and the degree of human interference is diverse (Photo 1, Fig. 1). The highest number of modifications was found in the Teesta Bazaar bridge section, where the right riverbank is reinforced with a concrete wall along its entire 
length. A smaller degree of river bank modification is observed in the Sikkim bridge section, where the reinforcements and reprofiling are only occasionally present in the top part of the left bank. The Sevok Bridge section is characterized by the smallest degree of modification of riverbank morphology. Morphological changes caused by human activity influence river habitat of rivers [21]. An expression of human changes in river habitat is the Habitat Modification Score $(H M S)$ index which indicates the degree of anthropogenic changes in the river hydromorphology. The Sikkim bridge and Teesta Bazaar bridge sections, with modifications in the morphology of riverbanks, i.e. reinforcements and reprofiling, are characterized by the greatest changes of the river habitat. The river habitat in those sections can be considered as significantly changed. The values of the HMS index equaled 29 and 34, respectively (Fig. 2). The Sevok bridge section, where the HMS value equaled 9 , is characterized by the least modified river habitat of the Teesta river, which is the result of the smaller transformation of river banks morphology in comparison to the other sections.

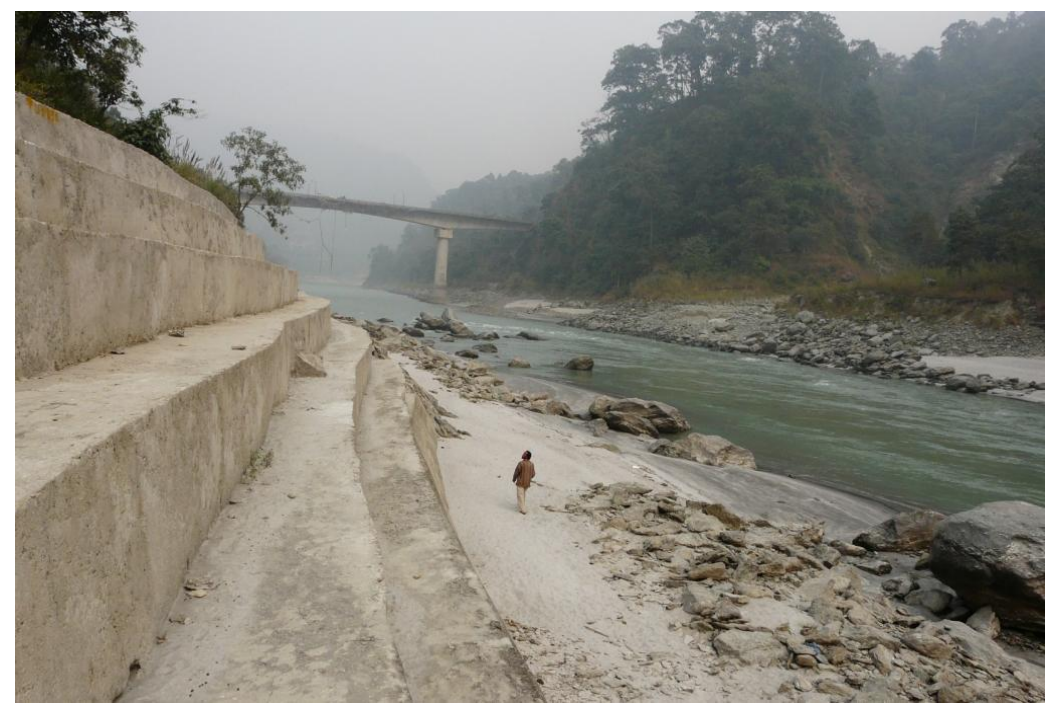

Photo 1. Reinforcement and reprofiling of the Teesta channel banks (Teesta Bazaar)

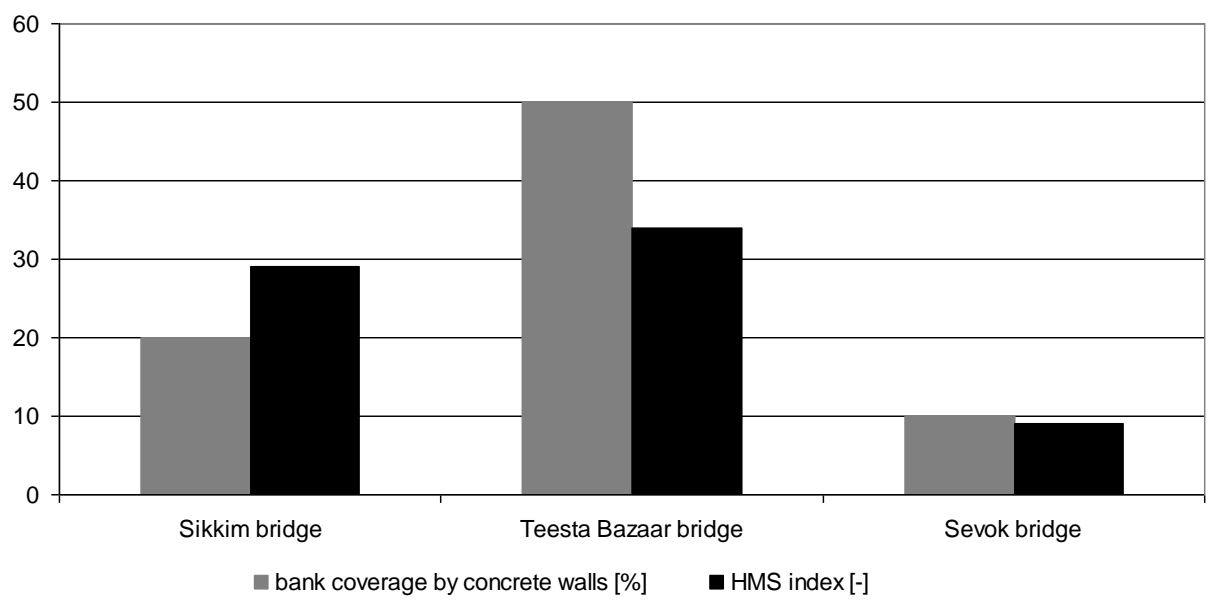

Figure 2. Values of HMS index and coverage of banks by the concrete walls on the bridge sections of the Teesta river

In the light of the growing demand for electricity, the Indian government has decided to double the current volume of its production using the energy potential of rivers, by 
building a large number of hydroelectric plants. One of the areas in which construction is carried out is Teesta river basin (Photo 2). The construction of many dams and water reservoirs within Teesta river basin will lead to significant transformations of the natural environment, including morphological changes in riverbeds [16]. Dams impose changes of flow and sediment transfer that drive changes of channel form along the downstream regulated river [22]. In the river channels above dams there is an intense accumulation of sediments, while below due to erosion there is a degradation of and dredging of the riverbed $[23,24,25]$. The Teesta river transports a large number of sediments, exploited in many places by local communities after the flood period [26]. The damming of the river will block the fluvial transport in the river and because of intensive accumulation within the channel and flood plain of the river will cause rapid shallowing of the river channel and the reservoirs.

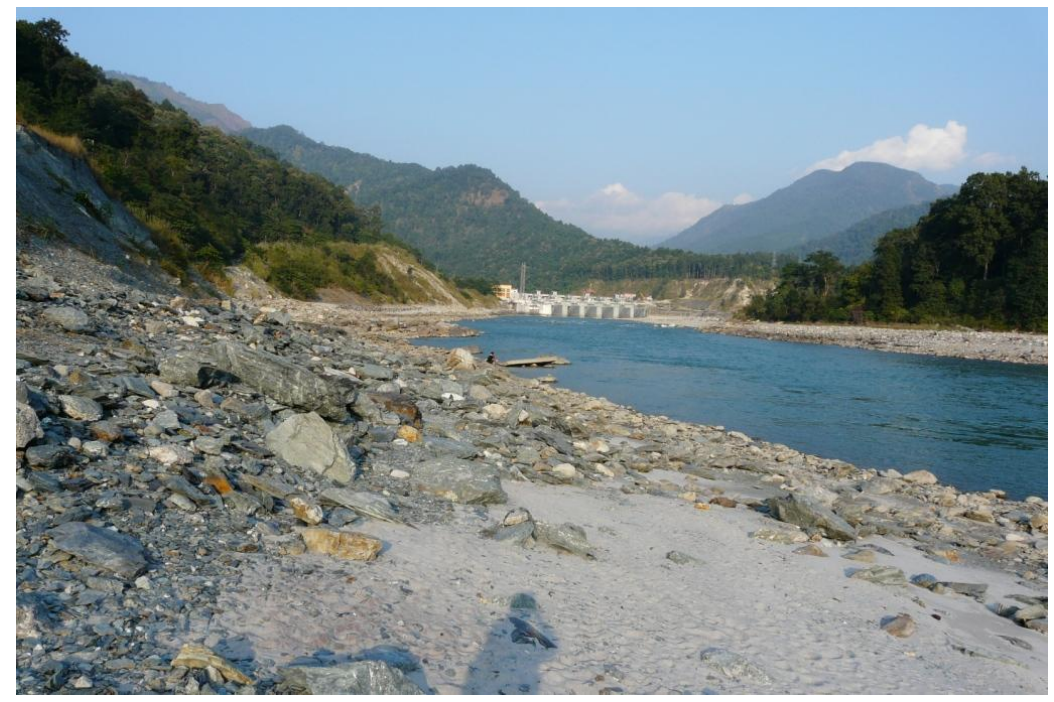

Photo 2. One of the new built dam (Teesta Low Dam III) on the Teesta river within the Himalayas

\section{Morphological consequences of human activity in the river channels at the piedmont of the Himalayas}

The Himalayas are a source of material transported by the flood during the monsoon season and deposited on their foreland. The scale of aggradation in river channels may reaches $3 \mathrm{~m}$ during 10 years [15]. The piedmont of the Himalayas is densely populated, which causes a strong human influence on river ecosystems. One of the most important manifestations of human activity in river ecosystems is the extraction of bed material [6]. The results of measurements of the bed position of the Lish and Gish river in the designated cross-sections at the Himalayan piedmont in 2011-2014 show their slow shallowing (Tab. 1). This suggest that the scale of material aggradation during the monsoon floods in the summer season is general greater than the scale of river material extraction by man. The observed raising of the bed level was in the Lish river $3 \mathrm{~cm} / \mathrm{year}$ and in the Gish river $0.5 \mathrm{~cm} /$ year. Research conducted on the tributaries of the Teesta river prove that the natural supply of bed material during floods does not always compensate the losses resulting from the extraction of material from the river. It results in cutting the riverbed into the ground. The field measurements show that the changes taking place in the bed of the Chel channel on the Himalayan piedmont were more complex than in the Lish and Gish river. The depth of the Chel channel in 2011 ranged 
from 5.15-8.30 m. In 2014, the extreme depths of the river bed were within the range of 5.25-7.20 m. From comparison of morphological cross profiles of the Chel river bed in the period 2011-2014 appears that in some places across the channel the tendencies of pronounced dredging were observed, while in others raising the bed level. The maximum local elevation of the bottom during the year reached $1.20 \mathrm{~m}$ and dredging $0.70 \mathrm{~m}$. The course of the average depth of the riverbed indicates that in the whole analyzed period there is a tendency to deepen the channel of $5 \mathrm{~cm} / \mathrm{year}$ (Tab. 1). This tendency can be combined with the mass extraction of bed material from the river.

The geomorphological effects of such form of anthropopressure in the above mentioned region have been presented in other scientific studies and the Balason river is one of the best studied rivers in this aspect in the North India, e.g. [27], [28]. Surveys conducted among the local community involved in extracting bed material from the Balason river (Photo 3) showed a significant dependence of the existence of the studied population on the work in the extraction of material, and the extraction will be continued [19].

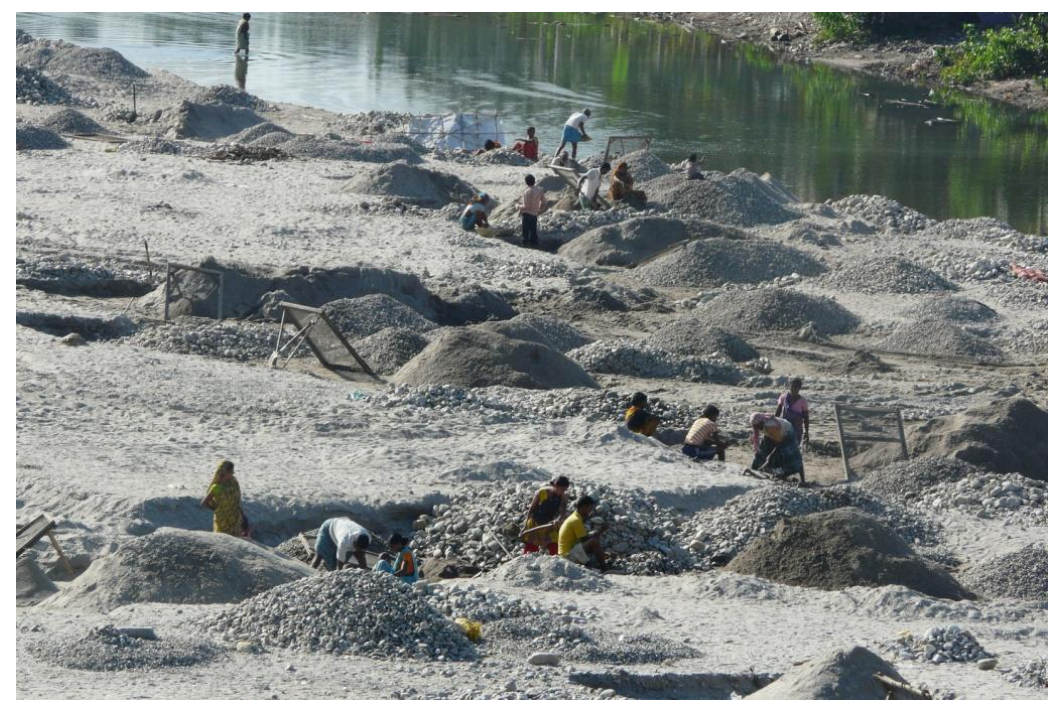

Photo 3. Bed material extraction from the Balason river by the local community (Nimtijot village)

\section{CONCLUSIONS}

The geomorphologic fieldwork carried out in the period 2011-2015 in the Teesta river basin within the Himalayas and its piedmont allows to formulate following conclusions: 1. Noticeable changes in the morphology of rivers are one of the most visible results of human activity in the Himalayas and its piedmont.

2. In the Himalayas deepening of river channels is a common natural morphological process, largely observed as the effect of frequent floods with high discharge. Human interference in the morphology of channels is visible in the form of bank modification by reinforcement and reprofiling. A serious threat to the morphology of the Himalayan channels is progressive construction of large number of dams what will lead to the high accumulation of bed material above reservoirs and faster deepening of channels below dams.

3. At the piedmont of the Himalayas the main natural morphological process within river channels is accumulation of material flowing out from mountains. In turn, the main human activity is revealed in the form of bed material extraction on a large scale. Such 
activity leads to the depending of channels in the situation of insufficient supply of bed material during floods.

Surveys conducted among the local community involved in bed material extraction from rivers showed significant dependence of the existence of local communities from the river resources (amount of bed material).

Due to the above findings further degradation of morphology thereby ecosystems of rivers in the Himalayas and its piedmont is expected.

\section{ACKNOWLEDGEMENTS}

This paper is the outcome of research collaboration between Institute of Geography and Spatial Organization, Polish Academy of Science and the Indian National Science Academy. I express gratitude to Prof. Subir Sarkar from Department of Geography, North Bengal University, who helped in organizing fieldwork.

\section{REFERENCES}

[1] Buffington JM. Changes in channel morphology over human time scales, in: Church M., Biron PM., Roy AG. (eds), Gravel-Bed Rivers: Processes, Tools, Environments, Chichester, UK, Wiley, pp. 435-463, 2012.

[2] Wiejaczka Ł., Kijowska-Strugała M. Assessment of the hydromorphological state of Carpathian rivers above and below reservoirs, Water and Environment Journal, vol. 29, no. 2, pp. 277-287, 2015.

[3] Kijowska-Strugała M. Sediment variability in a small catchment of the Polish Western Carpathians during transition from centrally planned to free-market economics, Geomorphology, vol, 325, pp. 119-129, 2019.

[4] Latocha A. Geomorphic connectivity within abandoned small catchments (Stołowe Mts, SW Poland. Geomorphology, vol. 212, pp. 4-15, 2014.

[5] Kijowska-Strugała M., Bucała-Hrabia A., Demczuk P. Long-term impact of land use changes on soil erosion in an agricultural catchment (the Western Polish Carpathians), Land Degradation and Development, vol. 29, pp. 1871-1884, 2018.

[6] Wohl E. Human impacts to mountain streams, Geomorphology, vol. 79, 217-248, 2006.

[7] Elosegi A., Díez J., Mutz M. Effects of hydromorphological integrity on biodiversity and functioning of river ecosystems, Hydrobiologia, vol. 657, pp. 199-215, 2010.

[8] Rasul G. Food, water, and energy security in South Asia: a nexus perspective from the Hindu Kush Himalayan region, Environmental Science and Policy, vol. 39, pp. 35-48, 2014.

[9] Kale VS. Fluvial geomorphology of Indian rivers: an overview, Progress in physical geography, vol. 26, pp. 400-433, 2002.

[10] Prokop P., Walanus A. Impact of the Darjeeling-Bhutan Himalayan front on rainfall hazard pattern, Natural Hazards, vol. 89, no. 1, pp. 387-404, 2017.

[11] Starkel L., Basu S. (eds.). Rains, landslides and floods in the Darjeeling Himalaya, INSA, New Delhi, 2000.

[12] Prokop P. Tea plantations as a driving force of long-term land use and population changes in the Eastern Himalayan piedmont, Land Use Policy, vol. 77, pp. 51-62, 2018.

[13] Soja R., Starkel L. Extreme rainfalls in Eastern Himalaya and southern slope of Meghalaya Plateau and their geomorphologic impacts, Geomorphology, vol. 84, pp. 170-180, 2007. 
[14] Sarkar S., Hydro-meteorological study of high intensity rainstorms in the Upper Tista Basin, (in:) Singh S., Sharma HS., De SK. (eds.), Geomorphology and Environment, Kolkata, ACB Pub., pp. 34-53, 2004.

[15] Starkel L., Sarkar S., Soja R., Prokop P. Present-day evolution of the Sikkimese-Bhutanese Himalayan piedmont, Geographical Studies, vol. 219, IGaSO PAS, Warsaw, 2008.

[16] Starkel L., Wiejaczka Ł., Kiszka K. Role of tributaries in shaping the middle course of the Himalayan River Teesta after the 1968 extreme floods, Current Science, vol. 112, no. 9, pp. 18961903, 2017.

[17] Wiejaczka $€$. Riverbeds level changes in the margin and foreland of the Darjeeling Himalaya during the years with a normal monsoon rainfall, [in:] Singh RB., Prokop P. (eds.). Environmental Geography of South Asia, Springer, Japan, pp. 83-95. 2016. DOI: 10.1007/978-4-431-55741-8_5

[18] Wiejaczka Ł., Bucała A., Sarkar S. Human role in shaping the hydromorphology of Himalayan rivers: study of the Tista River in Darjeeling Himalaya, Current Science, vol. 106, no. 5, pp.717-724, 2014.

[19] Wiejaczka Ł., Tamang L., Piróg D., Prokop P. Socioenvironmental issues of river bed material extraction in the Himalayan piedmont (India), Environmental Earth Sciences, vol. 77, no. 20, pp. 718, 2018.

[20] Lavé J., Avouac JP. Fluvial incision and tectonic uplift across the Himalayas of central Nepal, Journal of Geophysical Research: Solid Earth (1978-2012), vol. 106, pp. 26561-26591, 2001.

[21] Bucała A., Wiejaczka $Ł$. Evaluation of the hydromorphological state of mountain streams under the influence of contemporary human activity (Polish Carpathians), Environmental Earth Sciences, vol. 73, no. 7, pp. 3451-3463, 2015.

[22] Petts GE., Gurnell AM. Dams and geomorphology: research progress and future directions, Geomorphology, vol. 71, pp. 27-47, 2005.

[23] Brandt SA. Classification of geomorphological effects downstream of dams, Catena, vol. 40, pp. 375-401, 2000.

[24] Wiejaczka Ł., Kijowska-Strugała M. Dynamics of the channel beds level in mountain rivers in the light of the minimum water stages analysis, Carpathian Journal of Earth and Environmental Sciences, vol. 10, no. 4, pp. 105-112, 2015.

[25] Kijowska-Strugała M., Wiejaczka Ł., Gil E., Bochenek W., Kiszka K. The impact of extreme hydro-meteorological events on the transformation of mountain river channels (Polish Flysch Carpathians), Zeitschrift für Geomorphologie, vol. 61, no. 1, pp. 75-89, 2017.

[26] Wiejaczka Ł., Piróg D., Tamang L., Prokop P. Local residents' perceptions of a dam and reservoir project in the Teesta Basin, Darjeeling Himalayas, India. Mountain Research and Development, vol. 38, no. 3, pp. 203-210, 2018.

[27] De SK. A quantitative study of the longitudinal and cross -profiles (1989 -1994) of the River Balason in the Darjeeling District of West Bengal, Indian Journal of Geomorphology, vol. 15, pp. 67-80, 2010.

[28] Tamang L., Mandal DK. Bed material extraction and its effects on the forms and processes of the lower Balason River in the Darjeeling Himalayas, India, Geographia Polonica, vol. 88, pp. 393-405, 2015. 